\title{
Preparation and Characterization of Composite Phase Change Materials Containing Nanoparticles
}

DOI: $10.15255 /$ KUI.2016.015

KUI-41/2016

Professional paper

Received April 20, 2016

Accepted September 2, 2016

\author{
J. Yu, Z. C. Yu, C. L. Tang, X. Chen, Q. F. Song, and L. Kong \\ College of Aerospace and Civil Engineering, Harbin Engineering University, Harbin, P.R. China
}

\begin{abstract}
\| Abstract
The phase change thermal control method is now widely used in aircraft thermal protection due to its high energy density, constant temperature control, flexible operation, and many other advantages. ${ }^{1-6}$ However, thermal conductivity of most current phase change materials is low in phase transition process. ${ }^{7-10}$ This paper will add high thermal nanoparticles to phase change material in order to enhance the thermal conductivity, which, however, has some problems, such as settlement in the macro, reunion at the micro, etc. These problems also influence the improvement of the thermal conductivity. In view of this, a dispersing agent was introduced to these phase change materials, and then the mixed solution was subjected to ultrasonic dispersion. According to the test results, this treatment was effective in maximizing thermal conductivity of the composite phase change materials.
\end{abstract}

\section{$\|$ Keywords}

Nanoparticles, phase change materials, dispersant, ultrasonic dispersion, thermal conductivity

\section{Introduction}

The interior thermal environment is very important for the normal operation of aircraft. The interior equipment of aircraft generally requires temperatures in the normal range. For some detectors, such as infrared detectors, telescopes and others, a very low background temperature is usually required to decrease the thermal noise of background. In contrast, for some structural parts, temperature uniformity should be ensured in order to prevent thermal deformation of control structure members. To solve these problems, many methods for controlling temperature have been developed, of which phase change thermal control structure is a widely used method.

Phase change thermal control can absorb or emit a lot of heat through the phase transition process of the phase change materials, ${ }^{11}$ and thus provide or absorb heat for the spacecraft under harsh conditions of electronic components. This feature of phase change materials can ensure that aircraft work at an appropriate temperature. Further, if carbon foam is chosen as filling skeletons of phase change materials, the thermal conductivity of phase change materials can be significantly enhanced and thus realize the rapid absorption or release of heat. On this basis, if nanoparticles of high thermal conductivity are added to the phase change materials, the modified nanoparticles can significantly improve the thermal conductivity of the materials, ${ }^{12-14}$ which, however, has some problems such as settlement in the macro, reunion at the micro, etc.

In this paper, the mechanism enhancing the thermal conductivity of nanoparticles is explored. To overcome the

${ }^{*}$ Corresponding author: Dr Jia Yu

e-mail: 15146622389@163.com settlement of phase change materials, a dispersant is added to the composite phase change materials containing nanoparticles, and the appropriate ratio is determined. Furthermore, ultrasonic dispersion is conducted in order to disperse the nanomaterials more evenly. ${ }^{15}$

\section{Experimental}

The production of composite phase change material consists of melting a solid phase change material at first, then carbon graphite foam is impregnated in the molten phase change material under vacuum conditions, and finally cooled and solidified. Fig. 1 is a SEM photograph of a graphite carbon foam, showing the layered structure of typical graphite characteristics. In this paper, acetamide has been selected as the phase change material, because it has a larger phase change latent heat, chemical stability, reusability, and low cost advantages.
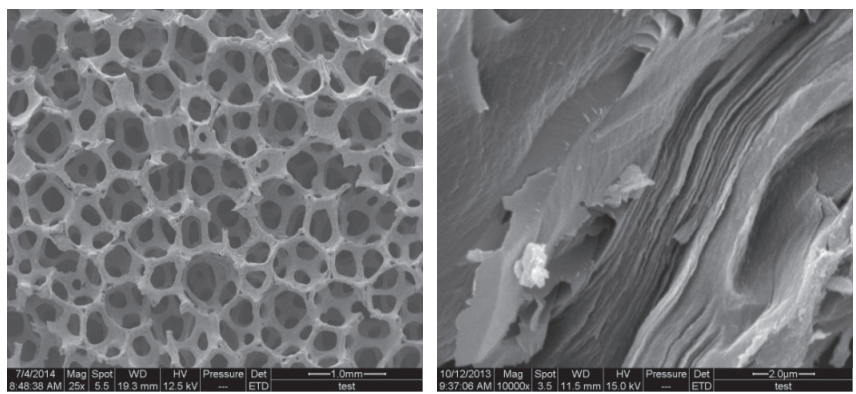

Fig. 1 - Electron micrograph of carbon graphite foam Slika 1 - Elektronska mikrografija grafitne ugljične pjene 
Based on a literature review, the thermal conductivity of phase change material can be improved by adding nanoparticles to the molten phase change material. Therefore, in this study, nanoparticles were used to dissolve the phase change material, then the composite materials were impregnated by carbon graphite foam to produce a composite phase change material containing nanoparticles, and the improvement of thermal conductivity was verified by experiments and simulation.

Nano-AIN, carbon nanotubes and graphene were selected as nanomaterials. AIN particle has a spherical shape, carbon nanotubes have one-dimensional elongated tubular shape, graphene has two-dimensional sheet structure - all three materials have different spatial structure. The three types of nanomaterial and their properties are shown in Table 1.

Table 1 - Nanomaterial properties

Tablica 1 - Svojstva nanomaterijala

\begin{tabular}{|c|c|c|c|c|c|}
\hline 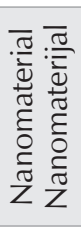 & $\begin{array}{c}\text { Average } \\
\text { particle size } \\
\text { /nm } \\
\text { Prosječna } \\
\text { veličina/nm }\end{array}$ & 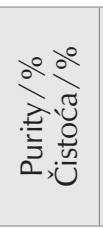 & $\begin{array}{l}\text { Form } \\
\text { Oblik }\end{array}$ & $\begin{array}{c}\text { Specific } \\
\text { surface area } \\
/ \mathrm{m}^{2} \mathrm{~g}^{-1} \\
\text { Specifična } \\
\text { površina } \\
/ \mathrm{m}^{2} \mathrm{~g}^{-1}\end{array}$ & $\begin{array}{l}\text { Density } \\
/ \mathrm{gcm}^{-3} \\
\text { Gustoća } \\
/ \mathrm{gcm}^{-3}\end{array}$ \\
\hline AIN & 40 & $>99$ & $\begin{array}{l}\text { spherical } \\
\text { sferičan }\end{array}$ & 70 & 3.5 \\
\hline CnTs & 15 & 99.5 & $\begin{array}{l}\text { chain } \\
\text { structure } \\
\text { lančast }\end{array}$ & 230 & 2.2 \\
\hline GnPs & $\begin{array}{c}\text { thickness } \\
0.8-8 \mathrm{~nm} \\
\text { particle size } \\
5 \mu \mathrm{m}\end{array}$ & 99.5 & $\begin{array}{l}\text { 2D sheet } \\
\text { 2D-ploča }\end{array}$ & 600 & 2.0 \\
\hline
\end{tabular}

By measuring the thermal conductivity of the composite material containing nanoparticles, it can be seen that the thermal conductivity of composite materials increases with graphene nanoparticles content, as shown in Fig. 2.

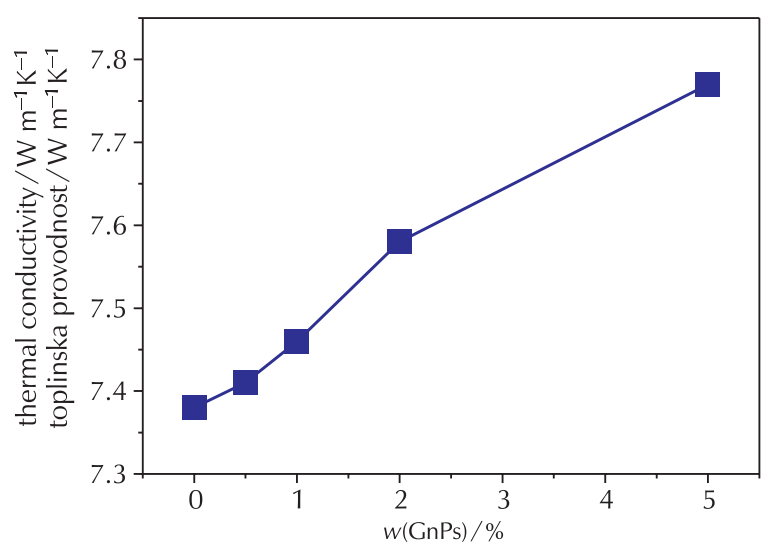

Fig. 2 - Acetamide-graphene-carbon foam thermal conductivity

Slika 2 - Toplinska provodnost ugljične pjene s acetamidom i grafenom
While adding the nanoparticles can improve the thermal conductivity of the composite, there are new problems in the process of adding nanoparticles, and these problems influence the improvement of the thermal conductivity of the composite material, which needs careful analysis and resolve.

Firstly, with the composite materials there occurs settlement under the influence of gravity after adding a large number of nanoparticles, thus affecting the thermal conductivity of the composite material. Therefore, we need to add a dispersant to improve the dispersion effect. In this paper, oleic acid was chosen as a dispersant. As oleic acid is a good dispersing agent, it can prevent mutual aggregation of particles, it is compatibility with the base fluid and particles, it has good thermal stability; it does not affect the performance of products; it is non-toxic and inexpensive; it is more hydrophilic and lipophilic. As shown in Figs. 3 and 4 , after the addition of oleic acid, the thermal conductivity of the composites (each containing aluminum nitride nanoparticles), the carbon nanotube nanoparticles and graphene nanoparticles show a certain upgrade.

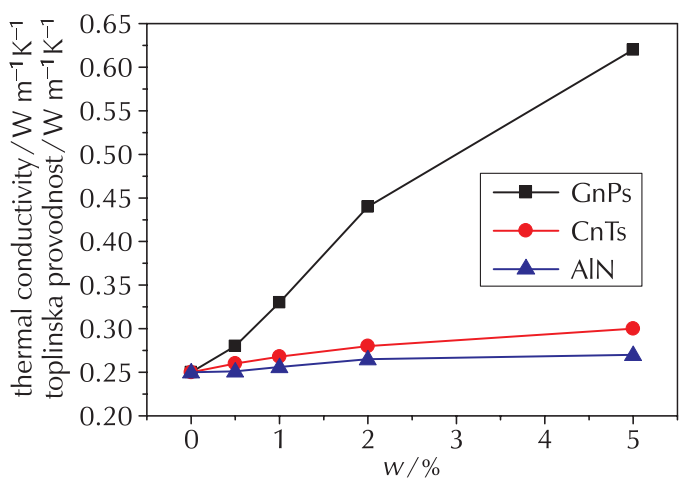

Fig. 3 - Thermal conductivity of acetamide before adding the dispersant

Slika 3 - Toplinska provodnost acetamida prije dodavanja disperzanta

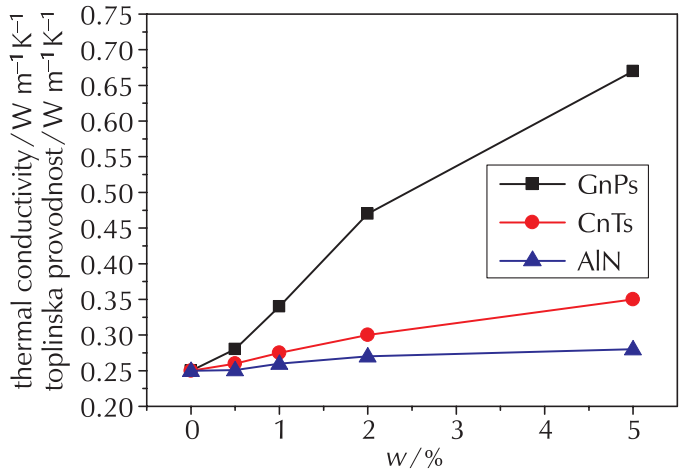

Fig. 4 - Thermal conductivity of acetamide after adding the dispersant

Slika 4 - Toplinska provodnost acetamida s disperzantom 
Secondly, in accordance with the single molecule adsorption principle formed on the surface of the dispersant molecules and nano-materials, when carbon nanotubes are dispersed, the theoretical amount of oleic acid in acetamide is calculated as follows:

Suppose the carbon nanotubes have a diameter of $10-15 \mathrm{~nm}$ and a length of $100 \mathrm{~nm}-1 \mathrm{um}$. In accordance with the cylindrical structure analysis, the surface area of upper and lower circularities is omitted.

Volume of carbon nanotube:

$V=\pi \cdot\left(15 / 2 \cdot 10^{-9} \mathrm{~m}\right)^{2} \cdot 10^{-6} \mathrm{~m}=1.77 \cdot 10^{-22} \mathrm{~m}^{3}$

Mass of carbon nanotube: $m=\rho \cdot v=1.48 \cdot 10^{-19} \mathrm{~kg}$

Surface area of the carbon nanotube: $s=9.42 \cdot 10^{-14} \mathrm{~m}^{2}$

Theoretical specific surface area: $\mathrm{s} / \mathrm{m}=636.86 \mathrm{~m}^{2} \mathrm{~g}^{-1}$

Due to high surface energy of nanoparticles, exotic atom adsorption, less layer of intertwined carbon nanotubes and other reasons, it is difficult to obtain the theoretical value of perfect dispersion under laboratory conditions. According to literature, the specific surface area of the carbon nanotube is $166.31 \mathrm{~m}^{2} \mathrm{~g}^{-1}$ at varying degrees of dispersion, and the cross-section of the polar tail of the oleic acid molecule is $4 \cdot 10^{-20} \mathrm{~m}^{2}$. Thus, the oleic acid that can be adsorbed on the surface of $1 \mathrm{~g}$ of nanoparticles is approximately $N=3.66 \cdot 10^{21}$.

$$
\begin{gathered}
n=3.66 \cdot 10^{21} / 6.022 \cdot 10^{23} \mathrm{~mol}^{-1}=6.08 \cdot 10^{-3} \mathrm{~mol} \\
\quad m=283 \mathrm{~g} \mathrm{~mol}^{-1} \cdot 6.08 \cdot 10^{-3} \mathrm{~mol}=1.72 \mathrm{~g} \\
\text { (relative molecular mass of oleic acid is } 283 \text { ) }
\end{gathered}
$$

Based on the above theoretical calculation, the mass of oleic acid dispersant is 1.7 times that of the nanoparticles.

Graphene and carbon nanotubes are made of similar materials, so the calculation method for graphene and carbon nanotubes requires the similar amount of oleic acid. The specific surface area of available graphene particles is $166.3 \mathrm{~m}^{2} \mathrm{~g}^{-1}$ according to the particle size analyser test. However, there is a gap between the real value of the specific surface area and the value of the particle size analyser test, because the liquid particles are considered spherical when the particle size analyser is in operation. While graphene has a two-dimensional sheet structure, it is known that in the same volume, the surface area of the sphere is the smallest, so the real data is much greater than $166.3 \mathrm{~m}^{2} \mathrm{~g}^{-1}$. Since we were unable to obtain the exact specific surface area of materials used in the experiment, we used $360-450 \mathrm{~m}^{2} \mathrm{~g}^{-1}$ as the amount of calculation, which was provided by the seller when the materials were bought. We can use the same method to calculate the mass of dispersant of graphene nanoparticles, which is 3.2 times higher. The specific surface area of nano-aluminum nitride is greater than $75 \mathrm{~m}^{2} \mathrm{~g}^{-1}$, so we can use the same method to calculate the mass of dispersant of aluminum nitride nanoparticles, which is 0.6 times higher.

Finally, we rendered the nanoparticles uniformly dispersed in the macro, although the addition of a dispersing agent, even under the influence of gravity, the composite material does not precipitate after a period of standstill. However, nanoparticle aggregates will still occur at the microscopic level, thus affecting the thermal conductivity of the composite materials. Therefore, in order to impact and penetrate particles in the solution persistently, it was necessary to use ultrasound, resulting in high local temperature and pressure or strong shock waves and micro-jet. While ultrasound causes the vibration of molecules in the medium, these vibrations can greatly weaken the energy between the nanoparticles, leading single nanoparticle of agglomeration to flake off in the solution, so that the nanoparticles spread out. This paper takes aluminum nitride nanoparticles and carbon nanotubes nanoparticles as an example, analyses the relationship between ultrasound time and the average particle size of nanoparticles.

The HYL-2080-automatic laser particle-size analyser was used for measuring particle size of materials. The volume average diameter was represented by the average volume of all particles per volume, which might represent the average size of dispersed particles. Acetamide was used as a phase change material, oleic acid as dispersant, and the ultrasound power was set at $1500 \mathrm{~W}$. The relationship between the volume average particle diameter of AIN and ultrasonic irradiation time is shown in Table 2:

Table 2 - Changes of the volume average particle diameter with ultrasonic irradiation time

Tablica 2 - Promjena prosječnog volumnog promjera čestica s trajanjem sonifikacije

\begin{tabular}{c|c|c|c}
\hline $\begin{array}{c}\text { Sonication } \\
\text { time } / \mathrm{min} \\
\text { Trajanje } \\
\text { sonifikacije } \\
\text { min }\end{array}$ & $w(\mathrm{AIN})=1 \%$ & $\begin{array}{c}\text { Average particle volume diameter } / \mu \mathrm{m} \\
\text { Prosječni obujamski promjer čestice } / \mu \mathrm{m}\end{array}$ \\
\hline 20 & 37.45 & 40.36 & 5.279 \\
30 & 7.623 & 13.11 & 3.399 \\
60 & 1.702 & 1.145 & 1.277 \\
90 & 1.466 & 1.394 & 1.282 \\
110 & 1.722 & 1.293 & 1.267 \\
130 & 1.392 & 1.312 & 1.212 \\
\hline
\end{tabular}

As shown in Table 2, after 90 minutes of ultrasound, different amounts of nanoparticles can all be dispersed sufficiently. From the economic and efficiency perspective, the ultrasonic irradiation time of 90 minutes is a reasonable time.

Fig. 5 shows the particle size distribution of carbon nanotube particles with ultrasonic irradiation time. At the beginning, the average particle size of agglomerated nanoparticles gradually decreases with time, and nanoparticles of larger size are dispersed. In this case, the volume average diameter declines from $72.58 \mu \mathrm{m}$ to $56.94 \mu \mathrm{m}$, and carbon nanotube aggregates of large size gradually disperse until complete disappearance. After ultrasonic dispersion for 60 minutes, the average particle diameter of carbon nanotubes gradually stabilizes at $20 \mu \mathrm{m}$ or less. At this moment, the distribution of particle size range of carbon nanotube 


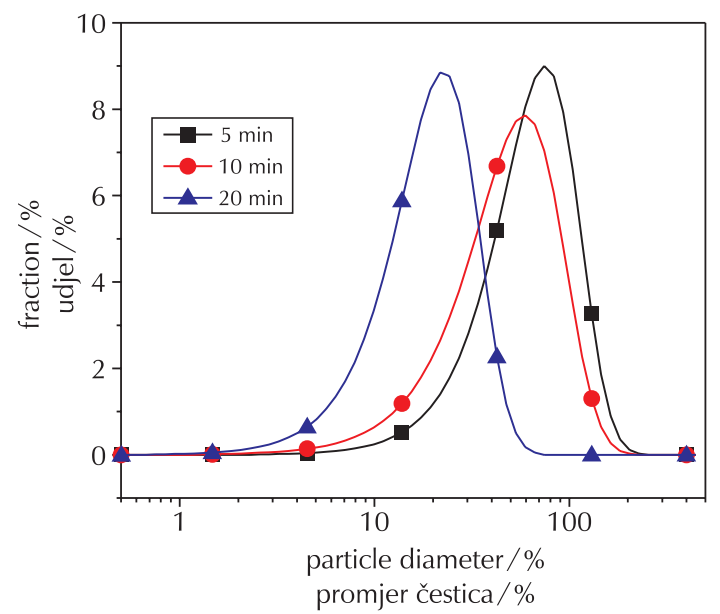

Fig. 5 - Particle size distribution of carbon nanotube particles with ultrasonic irradiation time

Slika 5 - Raspodjela veličine čestica ugljikovih nanocjevčica u ovisnosti o trajanju izlaganja ultrazvuku

groups is homogeneous, and every particle size range is stabilized. The decentralized system can obtain a smaller particle size after more than $1.5 \mathrm{~h}$, but beyond that time, it is not possible to further enhance the ultrasound effect.

\section{Results and discussion}

Through previous experiments, we found that adding nanoparticles to composite phase change material can improve its thermal conductivity. Simulation analysis was carried out in order to understand the mechanism of enhanced thermal conductivity of nanoparticles by ANSYS, and the simulation results were compared with the experimental results. Here, nanoscale graphene was chosen as nanoparticles, and acetamide was selected as the phase change material. The graphene was reduced to $2 \mathrm{~nm}$ side of the square, and its thickness was taken as the average value, i.e., $4 \mathrm{~nm}$. In order to reduce calculation amount, only the rotation in the xy plane of the graphene was considered. The graphene centre coordinate and inclination angle in the $x y$ plane were randomly generated with MATLAB. According to the actual situation, there was only an overlap but no intersection between the graphene particles.

Fig. 6 shows the 3D model of PCM-graphene. Since the model does not change the direction of thickness, it can be further simplified as a two-dimensional model, as shown in Fig. 7 (a), in which the volume fraction of graphene is $1 \%$ (mass fraction of $2 \%$ ). To study the effect of graphene shape on heat transfer, a spherical shape with a diameter of $40 \mathrm{~nm}$ can be established. Except the shape, other properties of the virtual particle model (Fig. 7 (b)) are the same as those of the PCM-graphene model. As shown in Fig. 7 (b), the volume fraction of virtual particles is $1 \%$.

From Fig. 7, although the fraction of graphene is very low, it partially forms a thermally conductive path, which is very beneficial for heat transfer. In contrast, if the graphene is of spherical shape, the particles are distributed substantially

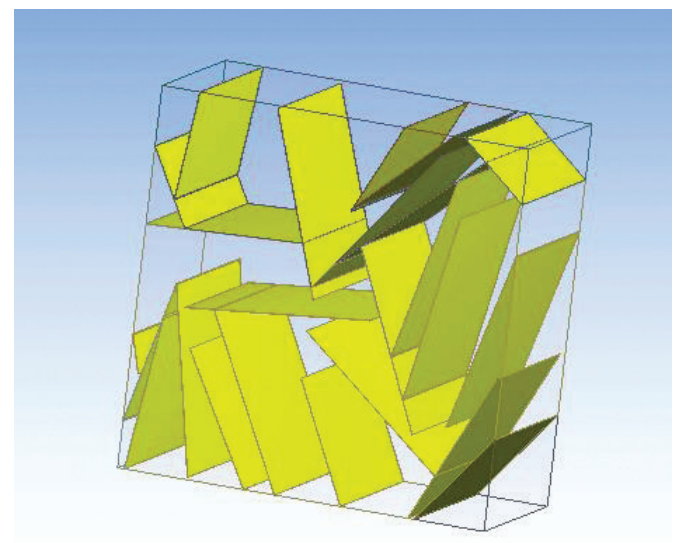

Fig. 6 - PCM-graphene 3D model Slika 6 - 3D-model PCM-a s grafenom

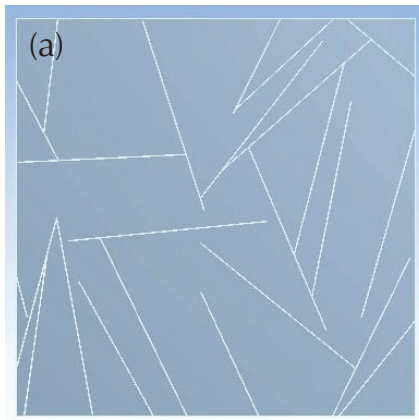

(b)

Fig. 7 - Simulation models of (a) PCM-graphene and (b) PCMvirtual particles

Slika 7 - Simulacija modela PCM-a s: (a) grafenom, (b) virtualnim česticama

independently in the material and cannot form a thermally conductive path although the content of virtual particles is the same as that of graphene.

Fig. 8 presents a phase change material - carbon foam model, in which the yellow part is the carbon foam skeleton and the translucent body is the phase change material around the carbon foam skeleton. This model is obtained through Boolean operations of a set of interconnected balls (Fig. 9) and a cube. It can adjust carbon foam porosity and pore size by adjusting the distance between the centre and the radius of the spheres. Herein, the porosity of the model is $90.18 \%$ and the pore size is $400 \mu \mathrm{m}$.

As can be seen from the temperature cloud in Fig. 10, temperature distribution becomes very tortuous due to heat transfer enhancement of graphene, and the heat of graphene is far greater than that of the phase change material. When the distance of the phase change material between two graphene particles is short, the heat flow greatly increases, which is conducive to the transfer of heat between the graphene and the formation of 


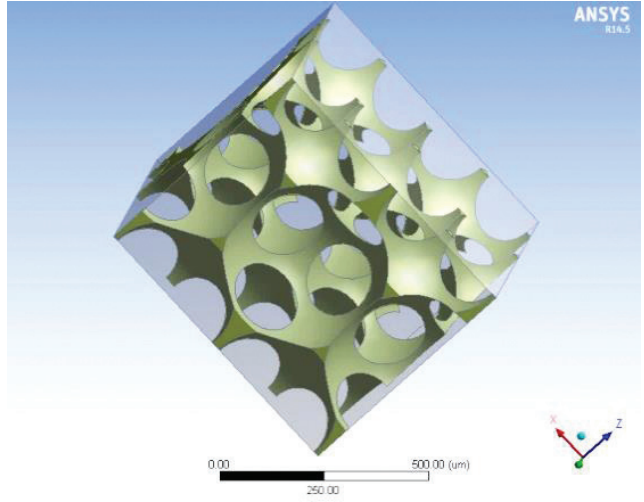

Fig. 8 - PCM-carbon foam model Slika 8 - Model ugljične pjene s PCM-om

a thermally conductive path. The temperature contour of Fig. 11 (a) is similar to that of pure material. A relatively high heat concentrates on the particles in the heat cloud of Fig. 11 (b), whereas the rest of the heat is very low. This indicates that the heat transfer enhancement effect of

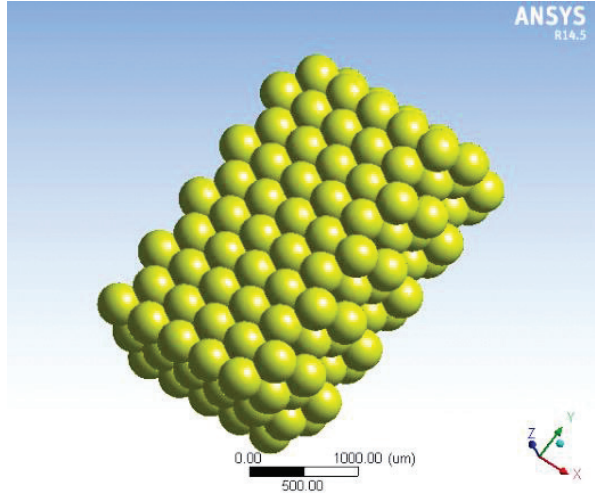

Fig. 9 - Interconnected balls Slika 9 - Povezane kuglice

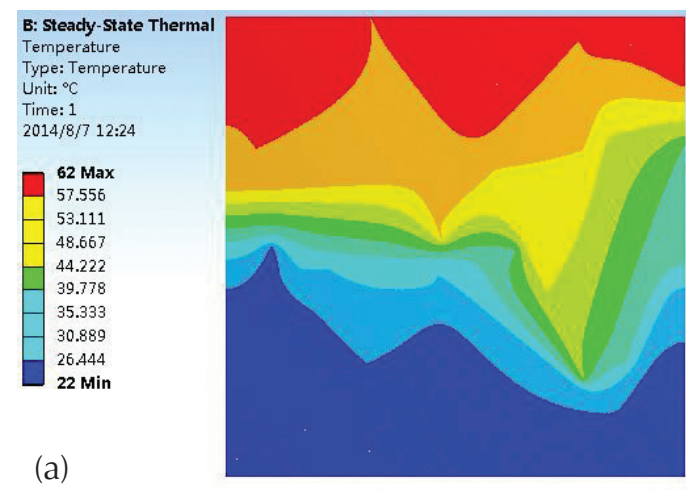

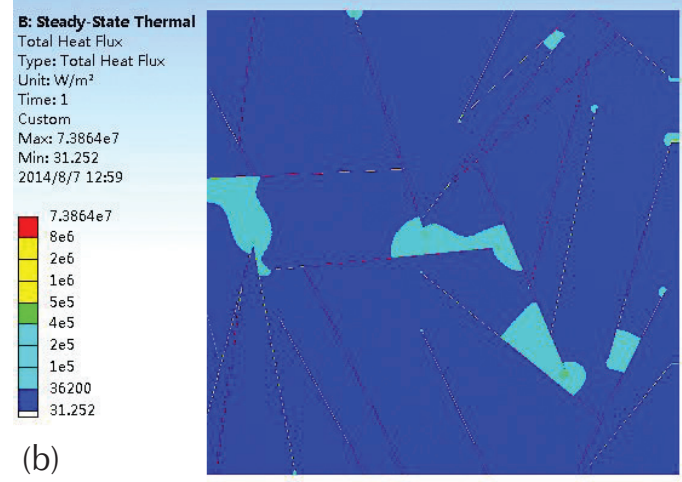
virtual particles is small. The thermal conductivity values of particle simulation of PCM-graphene and PCM-virtual without considering thermal contact resistance are $2.7566 \mathrm{~W} \mathrm{~m}^{-1} \mathrm{~K}^{-1}$ and $0.4380 \mathrm{~W} \mathrm{~m}^{-1} \mathrm{~K}^{-1}$ (that of pure acetamide is $\left.0.4289 \mathrm{~W} \mathrm{~m}^{-1} \mathrm{~K}^{-1}\right)$, respectively. It is noticed

Fig. 10 - (a) PCM-graphene heat transfer simulation temperature contours; (b) PCM-graphene heat transfer simulation of cloud

Slika 10 - (a) Simulacija temperature presjeka PCM-a s grafenom pri prijenosu topline; (b) simulacija prijenosa topline u PCM-u s grafenom u oblaku
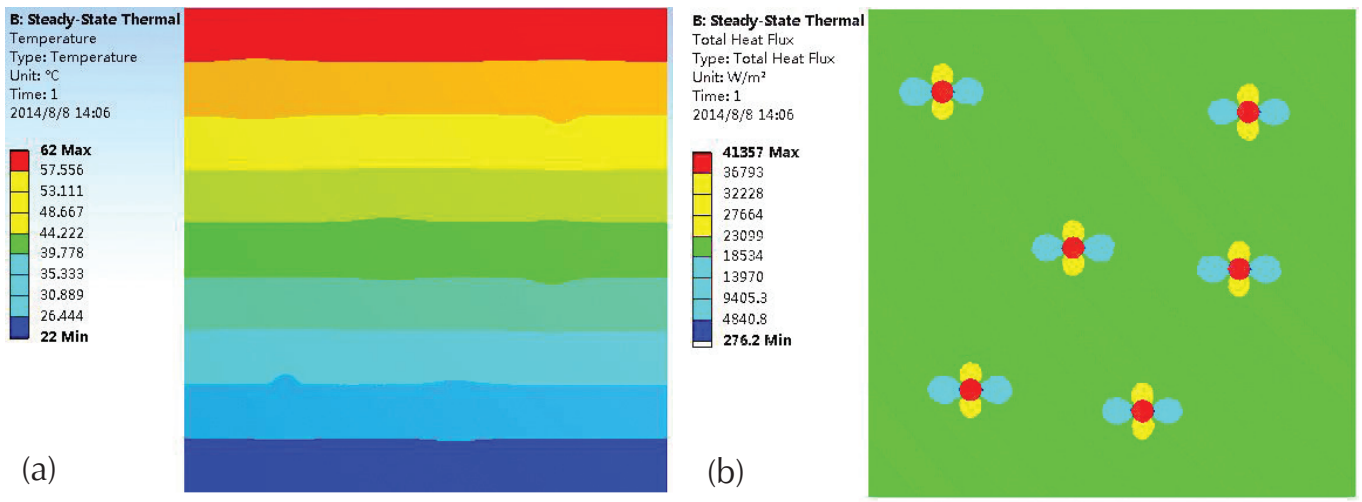

Fig. 11 - (a) PCM-virtual particle cloud temperature heat transfer simulation; (b) PCM-virtual particle cloud heat transfer simulation

Slika 11 - (a) Simulacija prijenosa topline PCM-a s virtualnim česticama; (b) simulacija prijenosa topline u PCM-u s virtualnim česticama 


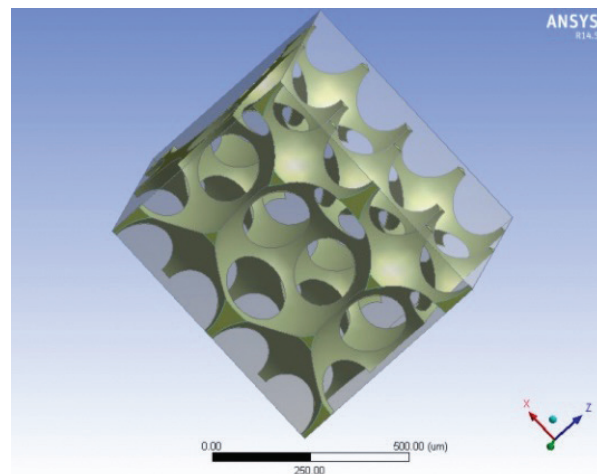

(a)

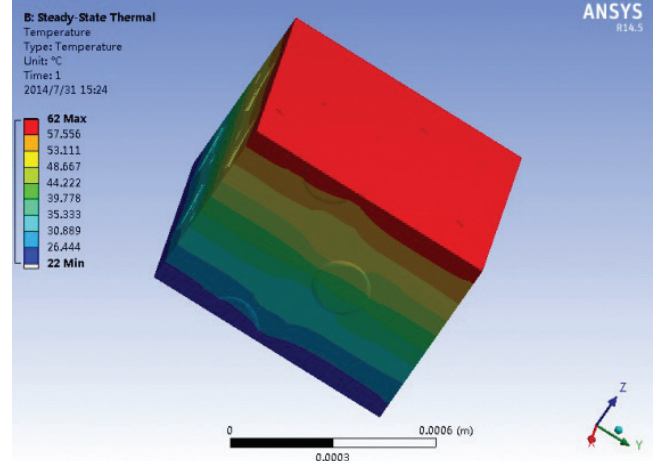

(b)

Fig. 12 - Numerical simulation of carbon foam phase change material: (a) model; (b) temperature cloud

Slika 12 - Numerička simulacija ugljične pjene fazno promjenljivog materijala: (a) model; (b) temperaturni oblak

that virtual particles and graphene have the same thermal conductivity and volume fraction in the simulation models, and that the only difference lies in their geometrical shape, namely the former is of spherical shape and the latter is of sheet shape. That is to say, the enhancement effect of sheet materials on thermal conductivity is much higher than that of traditional granular materials.

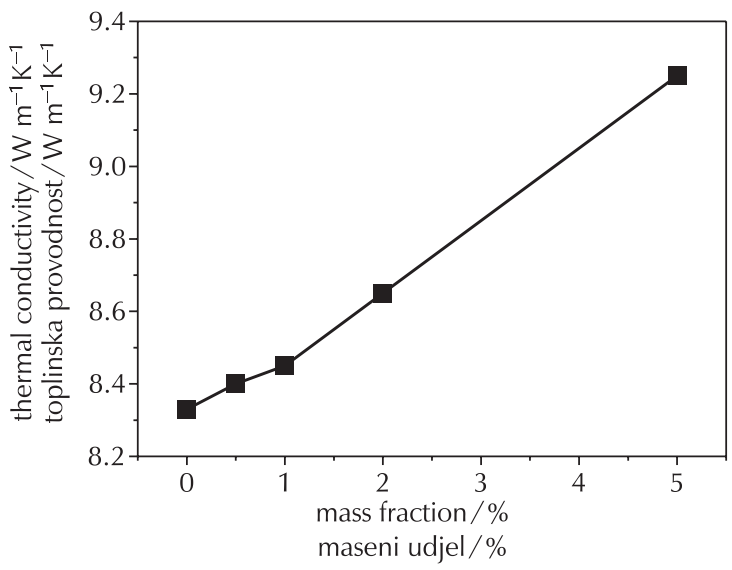

Fig. 13 - Acetamide-carbon foam thermal conductivity changes Slika 13 - Promjena toplinske provodnosti ugljične pjene s acetamidom

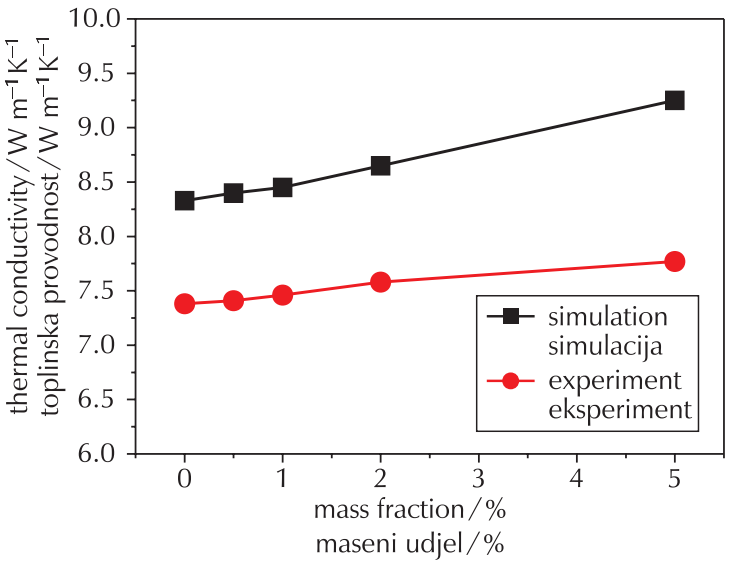

Fig. 14 - Thermal conductivity changes of simulation and experiment

Slika 14 - Simulirana i eksperimentalna promjena toplinske provodnosti

Fig. 12 shows PCM-carbon foam heat transfer simulation. This paper simulates the thermal conductivity of different graphene content samples based on this model. The simulation results are shown in Fig. 13. The simulation results in comparison with the experimental results with the addition of graphene nanoparticles is shown in Fig. 14. The trend curve of simulation and experimental results of the thermal conductivity is consistent, and the thermal conductivity increases. 


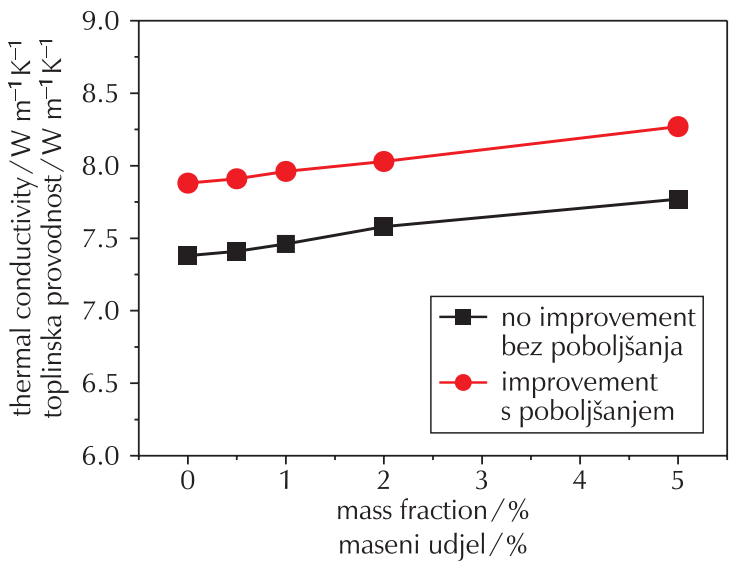

Fig. 15 - Thermal conductivity of composite phase change material

Slika 15 - Toplinska provodnost kompozitnog fazno promjenljivog materijala

Finally, this paper compares thermal conductivity of composite phase change material after addition of a dispersing agent and ultrasonic dispersion with thermal conductivity of composite phase change material before a addition of a dispersing agent and ultrasonic dispersion under different graphene content conditions, as shown in Fig. 15. After adding a dispersing agent and ultrasonic dispersion, the thermal conductivity of the composite phase change materials has a certain upgrade.

\section{Conclusions}

In this research, nanoparticles were added to the molten phase change material, then an appropriate amount of dispersant was added to the composite material in order to improve the dispersion, followed by ultrasonic dispersion, and finally graphite carbon foam was impregnated in the molten composite material, cooled, and solidified. The phase change material composite of higher thermal conductivity was prepared. Some conclusions can be drawn, as follows:

The addition of the nanoparticles to phase change material can improve its thermal conductivity.

The addition of a dispersant can improve dispersion of nanomaterials in the phase change materials. The appropriate amount of dispersant can be derived from theoretical calculations.

The average particle size of the composite phase-change material solution are reduced and the dispersion effect is improved after ultrasonic treatment, through experimental analysis that shows 90 minutes as the best ultrasound time.
The thermal conductivity curve of simulation and experimental results of composite phase change material have the same trend - the thermal conductivity increases with the addition of nanoparticles. Compared to the composite phase change material with only nanoparticles added, the composite phase change material has a higher thermal conductivity after addition of a dispersing agent and ultrasonic dispersion.

\section{ACKNOWLEDGEMENTS}

This article was accomplished under the loving care and guidance of tutor Yu Jia, here I have the honour to extend my sincere thanks and great respect to teacher Yu.

$$
\begin{aligned}
& \text { List of abbreviations and symbols } \\
& \text { Popis kratica i simbola } \\
& \text { CnTs - carbon nanotubes } \\
& \text { - ugljikove nanocijevi } \\
& \text { GnPs - graphene nanoparticles } \\
& \text { - nanočestice grafena } \\
& \text { PCM - phase-change material } \\
& \text { - fazno promjenjivi materijal } \\
& \text { m } \quad-\text { mass, } \mathrm{kg} \\
& \text { - masa, kg } \\
& \text { N } \quad \text { - number of particles } \\
& \text { - broj čestica } \\
& \text { n - amount of substance, mol } \\
& \text { - množina tvari, mol } \\
& \text { s - surface area, } \mathrm{m}^{2} \\
& \text { - ploština, } \mathrm{m}^{2} \\
& \text { V } \quad \text { - volume, } \mathrm{m}^{3} \\
& \text { - obujam, } \mathrm{m}^{3} \\
& \text { w } \quad-\text { mass fraction, } \% \\
& \text { - maseni udjel, \% } \\
& \text { - density, } \mathrm{kg} \mathrm{m}^{-3} \\
& \text { - gustoća, kg m }{ }^{-3}
\end{aligned}
$$

\section{References \\ Literatura}

1. G. Birur, K. Johnson, K. Novak, T. Sur, Thermal control of Mars lander and rover batteries and electronics using loop heat pipe and phase change material thermal storage technologies, SAE Technical Paper 2000-01-2403 (2000), doi: http://dx.doi.org/10.4271/2000-01-2403.

2. Z. Q. Hou, J. G. Hu, Spacecraft thermal control technology - Principles and Applications Beijing, China Science and Technology Press, 2007.

3. J. Finn, D. J. Ewing, L. Ma, J. Wagner, Thermal protection of vehicle payloads using phase change materials and liquid cooling, Proceedings of the 2010 American Control Con- 
ference (ACC), IEEE, 2010, doi: http://dx.doi.org/10.1109/ acc.2010.5531025.

4. K. Lafdi, O. Mesalhy, A. Elgafy, Graphite foams infiltrated with phase change materials as alternative materials for space and terrestrial thermal energy storage applications, Carbon 46 (1) (2008) 159-168, doi: http://dx.doi.org/10.1016/j.carbon.2007.11.003.

5. Z. Dong, Preparation and application experiments of energy-saving phase change energy storage material fly ash for building, Chongqing University, 2013.

6. Y. Liu, Preparation and performance study of fatty acid phase-change energy storage material, Nanjing University of Technology, 2011.

7. A. Elgafy, K. Lafdi, Effect of carbon nanofiber additives on thermal behavior of phase change materials, Carbon 43 (2005) 3067-3074, doi: http://dx.doi.org/10.1016/j.carbon.2005.06.042.

8. S. Shaikh, K. Lafdi, K. Hallinan, Carbon nano-additives to enhance latent energy storage of phase change materials, J. Appl. Phys. 103 (2008) 094302, doi: http://dx.doi. org/10.1063/1.2903538.

9. J. Wang, H. Xie, Z. Xin, Thermal properties of heat storage composites containing multiwalled carbon nanotubes, J. Appl. Phys. 104 (2008) 113537, doi: http://dx.doi. org/10.1063/1.3041495.

10. A. Elgafy, K. Lafdi, Effect of carbon nanofiber additives on thermal behavior of phase change materials, Carbon 43 (15) (2005) 3067-3074, doi: http://dx.doi.org/10.1016/j.carbon.2005.06.042.

11. Y. Wang, X. G. Liu, J. J. Yang. Progress of Phase Change Energy Storage Technology and Application, Heating 9 (2010) $10-12$.

12. S. P. Mo, Y. Chen, Reduction of supercooling of water by $\mathrm{TiO}_{2}$ nanoparticles as observed using differential scanning calorimeter, J. Exp. Nanosci. 8 (4) (2013) 533-539, doi: http://dx.doi.org/10.1080/17458080.2011.572085.

13. L. D. Jie, P. Hu, Sodium acetate trihydrate and other nanotechnology research performance nucleating agent, Heat 33 (8) (2012) 1280-1282.

14. N. N. Zhu, The influence of BN and AIN particles on the performance of thermal conductive silicone adhesive, Harbin Institute of Technology, 2011.

15. X. Wu, Y. Wang, S. Rong, M. Lai, R. Du, Z. Zhang, The anti-supercooling effect of surface-modified nano-scaled $\mathrm{SiO}_{2}$ in hydrated salts phase transition system, in Proceedings of the $8^{\text {th }}$ China International Nanoscience and Technology Symposium (CINSTS '09), Journal of Physics: Conference Series 188, 2009.

\section{SAŽETAK \\ Priprava i karakterizacija kompozitnog fazno promjenljivog materijala s nanočesticama \\ Jia Yu, Zhichao Yu, Chenlong Tang, Xuan Chen, Qingfei Song i Li Kong}

Toplinska kontrola fazno promjenljivim materijalima danas se široko primjenjuje u toplinskoj zaštiti letjelica zbog visoke gustoće energije, stalne temperaturne kontrole, fleksibilnog upravljanja i mnogih drugih prednosti. Nedostatak većine fazno promjenjivih materijala koji se sada upotrebljavaju je niska toplinska provodnost tijekom faznog prijelaza.

U ovom su radu fazno promjenjivom materijalu dodane dodane nanočestice izvrsnih termičkih svojstava da bi se povećala toplinska provodnost, ali se u tom slučaju pojavljuju drugi problemi, npr. slijeganje u makroskopskom mjerilu, udruživanje u mikroskopskom... Te pojave također utječu na toplinsku provodnost. Stoga je u fazno promjenjivi materijal dodan disperzant, a smjesa je dispergirana ultrazvukom. Ovakvom je obradom maksimizirana toplinska provodnost kompozitnog fazno promjenljivog materijala.

\section{Ključne riječi}

Nanočestice, fazno promjenjivi materijali, disperzant, ultrazvučno dispergiranje, toplinska provodnost

College of Aerospace and Civil Engineering, Harbin Engineering University, Harbin Kina
Stručni rad

Prispjelo 20. travnja 2016. Prihvaćeno 2. rujna 2016. 